Journal of the

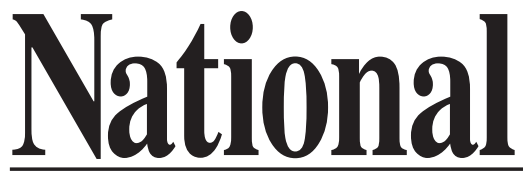

Academy or

Forensic
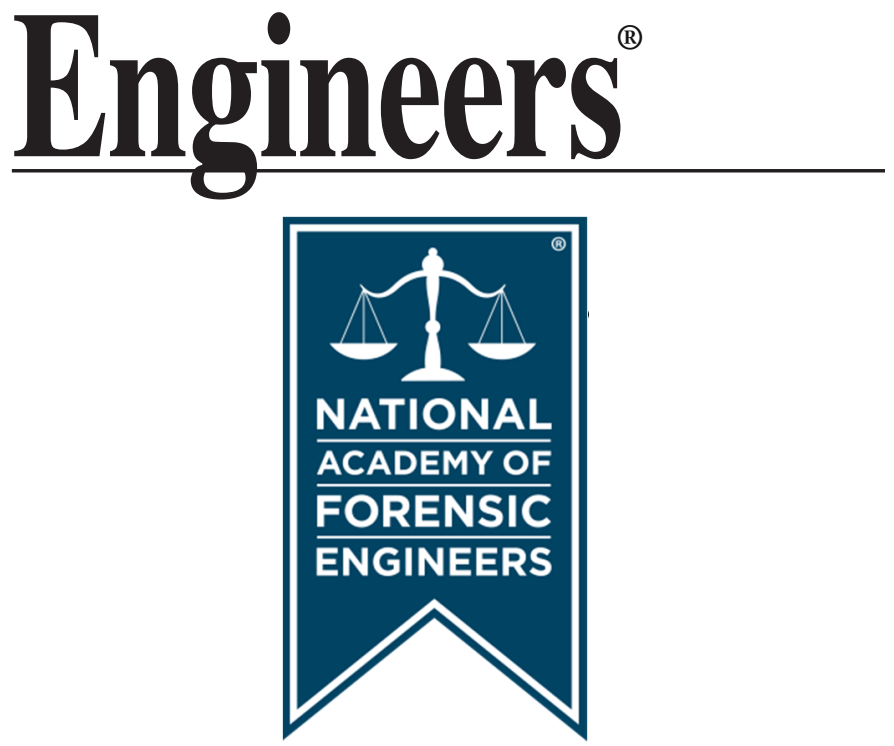

http://www.nafe.org ISSN: 2379-3252 


\title{
Forensic Engineering Investigation of Pyrite's Expansive Forces and Impact on Long-Term Building Failure
}

by Paul G. Carr, Ph.D., P.E. (NAFE 664S)

\begin{abstract}
There is a dearth of information available in the literature and published engineering texts addressing the impacts of pyrite expansion in buildings (Mitchell and Soga 2005). The texts have largely been silent, and the intersection of engineering geology, geotechnical engineering and foundation design has been lacking, with the exception of limited investigations related to highway engineering. Typically pyrite has been associated with shale materials when used as fill. Granite, as well as other rocks and soil can also contain sufficient pyrite to initiate the destructive forces associated with pyrite oxidation. In this case study paper, the insidious and destructive forces of pyrite expansion are presented. The long-term implications and strategies for remediation are considered.
\end{abstract}

\section{Index Terms}

Pyrite Oxidation, induced heave, expansive forces, foundation failure.

\section{Introduction}

Our involvement with the case began in the summer of 2002. We were retained to investigate numerous failures throughout multiple buildings in a school district in upstate New York, which had undergone a recent capital construction project.

The primary concern of the owner at that time was the movement within one of the elementary schools that had received an addition. The building is a reinforced load-bearing masonry structure with lateral forces resisted by masonry shear walls. The building had wracked under a lateral load, which had created a $1 / 4$ to $1 / 2$ inch crack between the interior shear walls and the interior and exterior perpendicular walls.

As a result of the investigation it was discovered that there were several sources of the failure of the lateral resistance system. The structural systems were inadequate to resist the design, or the experienced loads on the facility. The building was evacuated in May 2003, and temporary structural repairs were completed in the summer of that year. 
Copyright @ National Academy of Forensic Engineers (NAFE) http://www.nafe.org. Redistribution or resale is illegal Originally published in the Journal of the NAFE volume indicated on the cover page. ISSN: 2379-3252

During the investigation other structural errors were discovered, and remediation of those problems were also accomplished at the same time; summer 2003.

One situation observed in the investigation was the movement in the slabon-grade floor at the elementary school. It was discovered that there had been differential movement between the interior slab and the exterior foundation wall. As would be expected, the first impression was that the foundation had settled due to the concentrated forces on the exterior walls, transmitted to the foundation, while the floating slab inside the building was lightly loaded. This condition in 2003 is presented in Figure 1.

By the summer of 2003 it had been clearly established that the above ground structural system at this school was in need of remediation. However the differential slab movement remained unresolved. There were meetings with the designers and constructors of the building, and a general defensive theme relative to the foundation/slab movement was that the building was settling, the slab was not rising up.

\section{Background - General}

In January of 2003 a survey of the school had been completed to establish a baseline of elevations, since there was no 'as-built' survey performed at the time of construction completion. It was discovered that the slab within the building was higher in the center of the classrooms than at the edge, and the survey established that the edge of the slab was higher than the top of the exterior foundation wall. The cross-section in Figure 2 provides a graphical presentation of the survey results.

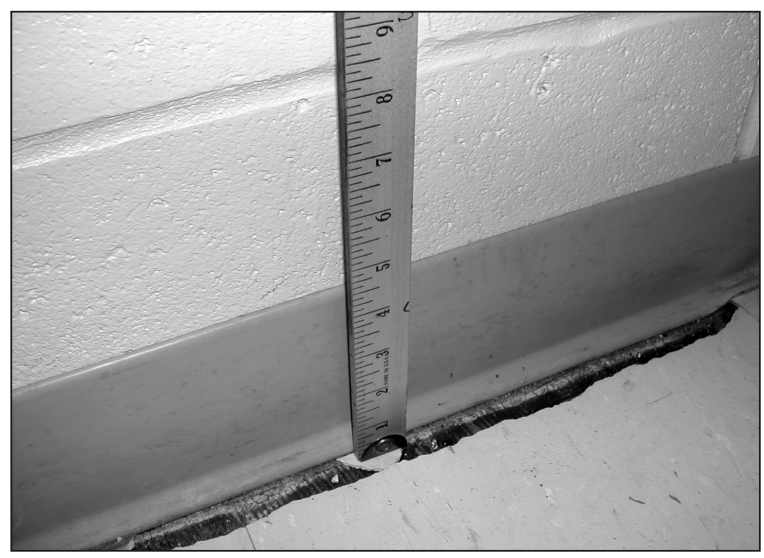

Figure 1

Differential Floor / Wall Movement

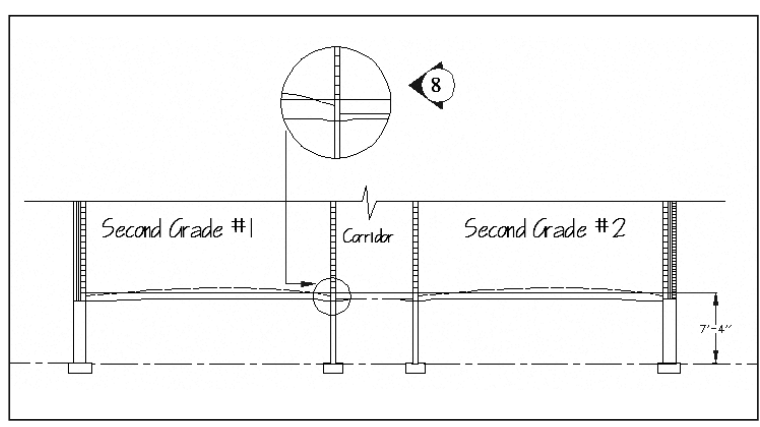

Figure 2

Cross-Section of Elementary School 
Furthermore, and critical to our investigation, it was established that the bottom of the brick veneer, on the outside of the building was essentially level all the way around the building addition, matching the brick of the original building. The survey showed that the centerline elevation of the corridor was level from the point of connection to the existing school to the end of the new addition. Yet, even though all of this data pointed to heave in the classroom, no proof of the cause was available, thus the original project team's defense continued that the this was a foundation problem that the owner should address with the geotechnical engineer that had been retained by the district to provide the designer with foundation recommendations.

The designer had generally followed the recommendations of the geotechnical report when designing and specifying the foundation systems for the capital project. The designer had called for an engineered structural fill for the fill within the building area. This was specified through a note on the drawings (Figure 3). The contractor however had deviated from the specified design when he requested to substitute the material used for the fill within the foundation of the structure.

32 ENGINERES STRUCIURAL FUL SHMU BE PROMBED AS FIL WTHIN THE BUILONG AREA INCLUOTNG A DISTANCE GF 5 FEET BEYOND THE PERILETER. IT SHALE. CONSIST OF A CUEAN, SCRECNEO. CRUSHED OR BANK-RUN GRAVEL CONFORUING TO TME FOLLOWNG GRADATIONE. ENGNESRED STRUCFURAL SILL

SIEVE S\&ZE

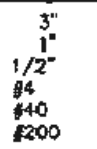

PERCENT PASSING

100

$80-53$

45-75

$30-80$

$10=40$

$0-7$

THIS MATERIAL WLL NEED TO EE OBTAINED FRON AN OFF-SITE SOURCE.

\section{Figure 3}

Drawing Note Requiring Engineered Fill within the Building

This fill, at the elementary school ranged from approximately 1-foot to over 6 -feet in depth. It was specified to be an engineered structural fill, and the contractor requested to use stone dust as a substitute for this material. Figure 4 shows the first lift of the substitute stone dust installation. The granite stone dust when placed was light gray in color as was noted in the color construction photos.

In July of 2003 we retained the services of a geotechnical consultant to assist in the investigation. Cores were drilled through the concrete floor slab at three locations in the most affected classrooms, and backfill samples were collected. The fill material collected in these samples did not appear to be the material that was to have been placed within the foundation. The samples collected appeared to be sand, not stone dust as had been reported, and had been 
evidenced in the project photos. This material collected was strikingly brown in color, in contrast to the construction photos of the gray stone dust being placed.

The appearance of the "sand like" material collected by the geotechnical engineer, further confounded the investigation. In addition, the slab cored adjacent to the exterior

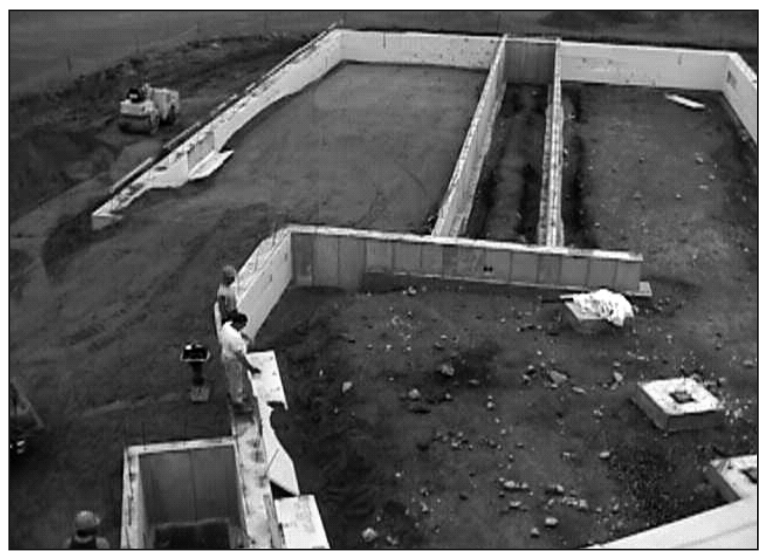

Figure 4

Elementary School Foundation with Initial Lift of Substitute Material wall in the end classroom was found to have a $3 / 4$ to 1 -inch space below the concrete floor slab and the top of the fill material. This suggested that the foundation and adjacent backfill material under the floor slab might have settled, thus creating this space. It could also have indicated that the center of the slab was lifting, raising the edge of the slab with it. Without as-built survey data, and with such a slow movement of heave, there was no answer here.

The geotechnical engineer was tasked with determining the physical characteristics of the soils, and to test the collected material for swell [expansion] potential. These tests were completed, and the tests indicated that the material

\section{Laboratory Swell Test Report}

Samples obtained from Core Location C-1 and C-3, LN's 5194 and 5197

Compacted Wet Density (pcf)

LN-S194

Compacted Dry Density (pef)

141.9

Compacted Moisture Content (\%)

127.5

Final Moisture Content (\%)

13.8

Maximum Indication of Swel] (in.)

11.3

Inundation Buration (hours)

Final Indication after draining (in.)

87.0

Molded Height of Specimen (in.)

Max Indication of Swell (\%)

Final Indication of Swell (\%) 
was physically similar to the material submitted as a substitute for the structural fill, even though its visual appearance was significantly changed.

As seen in Figure 5 - the Final Indication of Swell is at $0.00 \%$. Even with the greatest measured swell at $0.09 \%$ this would result in less than 1/16th of an inch swell in a five-foot thick layer. Thus with these test results the theory of material swell was abandoned in 2003.

\section{Alternative Theories}

At that time alternative theories were developed, with significant consideration given to the possibility that the exterior foundation had in fact settled. It was agreed that the school would retain a surveyor to measure the building and monitor its movement. Additional marks were placed on the walls to track the relative movement of the building.

In the winter/spring of 2004 it was reported by the school that the building had continued to move and we again mobilized for further field studies. It was posited that the spring runoff from the hillside above the school might contribute to the lifting of the slab through some form of underground spring, causing an upward pressure on the floor slab within the building foundation area. Test gages were purchased, installed and monitored. No pressure differential was recorded.

In February 2005 we directed the installation of additional movement gages at strategic locations within the 1998 addition to attempt to track any minute movement more precisely, even though there had been no reports from the district's surveyor of any measurable change. It was during this visit that the building's continued movement was clearly evident. We requested that the school district's survey firm again do a field check. The survey results reported that the building slab had indeed risen up more. In March 2005 we meet with school's original geotechnical engineer, and jointly visited the site. The concept was to involve the original soils engineer again, and investigate the potential for the movement due to frost heave.

By the end of March the building had moved again. The movement gage installed on February 23, 2005 showed a 1mm movement in a one-month period.

Various efforts were made by the original geotechnical firm to measure ground water and to investigate the potential for frost heave. The school representatives believed that water was a contributing factor to the problem at the school. We could not disagree with the assessment, yet still we had no firm cause and effect relationship established. It was believed that frost penetration might be a contributing factor to the problem. 
Copyright @ National Academy of Forensic Engineers (NAFE) http://www.nafe.org. Redistribution or resale is illegal Originally published in the Journal of the NAFE volume indicated on the cover page. ISSN: 2379-3252

The original geotechnical investigation performed in 1995 determined the type and character of the in-situ soils found on the site at the location of the planned addition. One item the investigation evaluated was the density of the soil in each core boring, across different vertical locations. The material characteristics under the footing were identified by relatively high "blow counts" [100+/-]. The blow counts of 100 in this zone indicate extremely dense material. It is on this dense underlying soil layer that the footings were placed.

The implication is that as the surface water sheds from the building, it passes through the porous sand exterior backfill, downward through the soil. It will then either be captured in a footing drain [of which there was none designed, nor installed] or it will continue downward into the native soil mantle. With this underlying soil quite dense, the ability

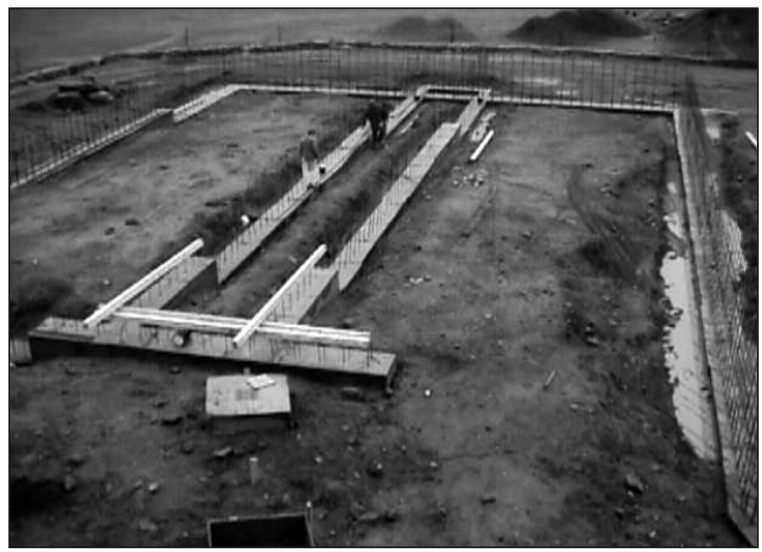

Figure 6

Water Trapped Adjacent to Footing of the water to penetrate into the native soil is limited; therefore it will be captured at the base of the foundation wall. The footing, once in place, and without a footing drain, has created a moat around the building that allows water to be captured and to stand in place without the opportunity to freely drain away. This is shown in Figure 6.

The implication of this moat adjacent to the foundation is that there is now a source of water to add to the deleterious effects associated with the fill materials.

We know that the material that was substituted for use as a structural fill is frost susceptible. The quantity of fines in the material [defined by the amount passing the 200 sieve] is enough to induce a capillary flow of water into the soil. The substituted stone dust material with 11 to $15 \%<200$ sieve material will not only draw the water, but will hold the water for long periods of time within the enclosed foundation wall system.

If we had frost susceptible fill material, with significant fines content, a water source and cold temperatures, then the three necessary ingredients for frost penetration existed, thus our frost investigation continued. 
Copyright @ National Academy of Forensic Engineers (NAFE) http://www.nafe.org. Redistribution or resale is illegal. Originally published in the Journal of the NAFE volume indicated on the cover page. ISSN: 2379-3252

NAFE 664S

PYRITE'S EXPANSIVE FORCES

PAGE 7

The computed frost potential and the movement of the building over time were evaluated. It was found that the building had in fact continued to move since its construction. The building's rate of movement was increasing with time and that at the edge of the building, where the interior shear wall tied to the exterior wall, had a differential movement of over $22 \mathrm{~mm}$.

The school was advised concerning the concept of the installation of footing drains around the perimeter of the building. We reported to the Board on the potential for frost heave, and that while the control of water adjacent to the footing was a reasonable prophylactic measure, we did not believe that frost was the problem; and therefore the drains would likely not be the final solution. The footer drain project moved forward and was completed in the summer of 2005 . We continued monitoring the site throughout 2005.

The crack monitoring gages were reset to zero after the drainage was installed. The site was visited in August, when the movement monitors had been in place for about one month, and when there was no frost present. The movement gage showed continued movement of $1 \mathrm{~mm}$ upward and $1 / 2 \mathrm{~mm}$ outward within the month of August, even though there was no frost penetration.

It was not evident that there were additional factors moving the building's floor other than the potential impact of frost penetration. Our investigation took yet another direction.

\section{Alternative Theory and a New Direction}

In March of 2005 we consulted several of my colleagues at Cornell to solicit their input. Dr. Fred Kulhawy and Dr. Thomas O'Rourke observed the soil samples that had been collected [and retained] from the summer of 2003 during the core boring investigation (O'Rourke and Kulhawy 2005). It was seen that the samples had dried out, and upon a detailed inspection it was noted that the material was in fact, not the sand reported within the 2003 geotechnical consultant's investigation, but that it was actually the crushed granite stone dust. It was the same material substituted and approved for placement at the project, yet it was now brown.

The crushed granite fines had undergone some form of phase change where the fines had oxidized and turned brown, yet when wet appeared to be a sand product. Upon discussion with my colleagues we then returned to the theory of material expansion due to swell previously abandoned after the swell tests had reported a negative potential.

The investigation had now returned to the theory that some constituent within the granite fines could be contributing to the expansion of the structural 
Copyright @ National Academy of Forensic Engineers (NAFE) http://www.nafe.org. Redistribution or resale is illegal. Originally published in the Journal of the NAFE volume indicated on the cover page. ISSN: 2379-3252

PAGE 8

DECEMBER 2008

NAFE 664S

fill. One such material known to exhibit these characteristics is pyrite. The stone supplier assured us that there was little or no pyrite in the granite at the site of their operation, however this theory was followed.

\section{Site Conditions and Specified System}

The footing drain installation in the summer of 2005 allowed us to observe and collect additional material for analysis. The footer drain was installed at the bottom of the footing elevation, and the foundation wall was exposed for the drain installation. Core drilling of the concrete foundation wall allowed us to collect additional samples of the structural fill under the slab-on-grade. The material collected had the same "wet sand' appearance as the samples collected by means of core drilling the floor in 2003. Figure 7 depicts the material taken from the cores along the foundation wall. This material appears as wet sand (brown in color) and does not resemble the gray stone dust from the construction photos.

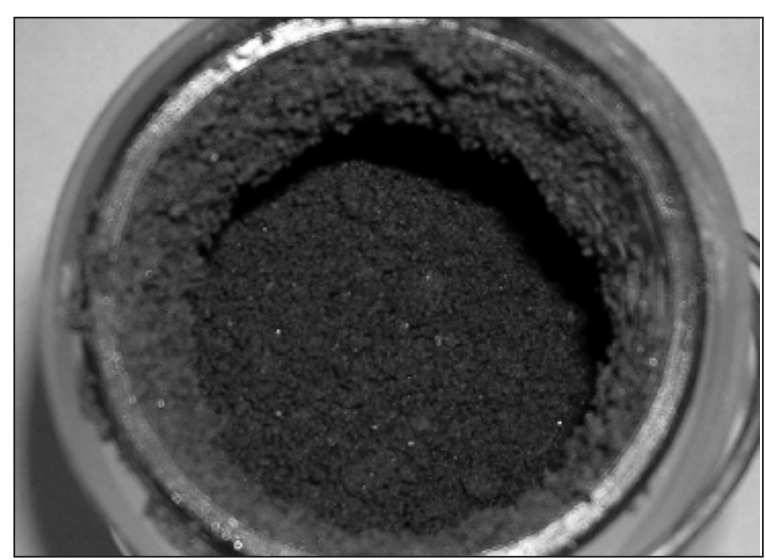

Figure 7

When constructed the exterior of the building's foundation was backfilled with a sand material. This sand was observed to be dry during the foundation drain excavation, yet the material collected through the core samples under the building was saturated.

\section{Substitution of Specified Material}

As previously indicted, changes were made in the construction of this project. The material used for structural fill is physically very different from the material that had been specified.

The material that had been specified for use was an engineered structural fill, with less than $7 \%$ minus 200 -sieve material. This fill would be a welldrained, stable material.

The material substituted for this structural fill material contained double the amount of fines, and had $100 \%$ less than $1 / 2$ inch material. In fact, upon observation it can be noted that $100 \%$ of the material was less than $1 / 4$ inch. The specified material was to have no less than $75 \%$ less than $1 / 2$ inch. 
Copyright @ National Academy of Forensic Engineers (NAFE) http://www.nafe.org. Redistribution or resale is illegal. Originally published in the Journal of the NAFE volume indicated on the cover page. ISSN: 2379-3252

NAFE 664S

PYRITE'S EXPANSIVE FORCES

PAGE 9

While public projects in New York State require the acceptance of equivalent materials, the process of acceptance or rejection varies with designers. In this case the substitute material was allowed for installation.

\section{Building Heave Cause and Effect}

The material in the project photos showing placement within the building is the same material proposed by the contractor - however the in-situ samples collected by the geotechnical engineer in 2003 and by us in 2005 appeared different [the fines had changed to a brown color]. The two materials are virtually identical from a physical (gradation) standpoint. The conversion of the crushed granite from gray to brown indicated a phase change due to an oxidation process. It was theorized that this change was the result of pyrite present in the source material.

\section{Cause}

Pyrite, $\left[\mathrm{FeS}_{2}\right]$ when exposed to water and oxygen undergoes a chemical reaction called sulfation - this releases insoluble iron oxides and sulfuric acid, allowing acidic conditions to form, which in turn creates expansive forces (Bryant, 2003, Mitchell, 2004). It is these expansive forces, resulting from the physical/chemical reactions, which contribute to the lifting of the slab.

The chemical reactions are:

$$
2 \mathrm{FeS}_{2}+2 \mathrm{H}_{2} \mathrm{O}+7 \mathrm{O}_{2} \rightarrow 2 \mathrm{FeSO}_{4}+2 \mathrm{H}_{2} \mathrm{SO}_{4}
$$

In the continuation of the chemical reaction, and in the presence of Calcium $(\mathrm{Ca})$, the sulfuric acid and water create gypsum $\left(\mathrm{CaSO}_{4}\right)$ with its attendant large volume increases, and expansive force.

$$
\mathrm{H}_{2} \mathrm{SO}_{4}+\mathrm{CaCO}_{3}+\mathrm{H}_{2} \mathrm{O} \rightarrow \mathrm{CaSO}_{4}+2 \mathrm{H}_{2} \mathrm{O}+\mathrm{CO}_{2}
$$

One problem is that not all pyrite is visible to the naked eye. Therefore its detection can be difficult at times, and the reality is that it takes a very small amount of pyrite to create significant expansion forces within a fill material. As little at 1/10th of 1 percent of the material in the fill material can initiate expansion (Belgeri and Siegel, 1998).

Given the nature of pyrite relative to other minerals known to be in the supply quarry this small percentage of pyrite can present a problem. Bryant quotes Cripps, et al in her work. The implication of the term invisible menace becomes clear. "Unfortunately, while these micro-crystalline sulfide materials are the most problematic, they are also the most difficult to identify visually due to their small grain size. As a result, pyrite has been called the "invisible menace" 
Copyright $\odot$ National Academy of Forensic Engineers (NAFE) http://www.nafe.org. Redistribution or resale is illegal. Originally published in the Journal of the NAFE volume indicated on the cover page. ISSN: 2379-3252

since pyrite is most dangerous to engineered systems when it is too fine-grained to be visible" (Bryant, 2003).

Once the pyrite is in the finest of particles, the surface area is much greater therefore the oxidation process will increase in time and completeness.

The forces created by the oxidation of pyrite are reported to be substantial. Belgeri reports the magnitude of these forces as 70 to $75 \mathrm{kPa}$. Since one $\mathrm{kPa}$ is equal to $0.145 \mathrm{psi}$, pressures of over $10 \mathrm{psi}$ within the fill material are possible.

The question then arises as to what forces would be required to raise the floor slab. The floor itself was cored and found to be approximately 6-inches thick. This would then weigh $\sim 75$ pounds per square foot, or $\sim 0.52 \mathrm{psi}$. The fill material immediately under the slab at 125 pounds per cubic foot would then add a resistance of $\sim 1.3 \mathrm{psi}$. The structural fill at 142 pounds per cubic foot would add $\sim 5.9$ psi for a six foot depth. This all adds to less than the expansive forces that could be experienced even at the lowest level of the

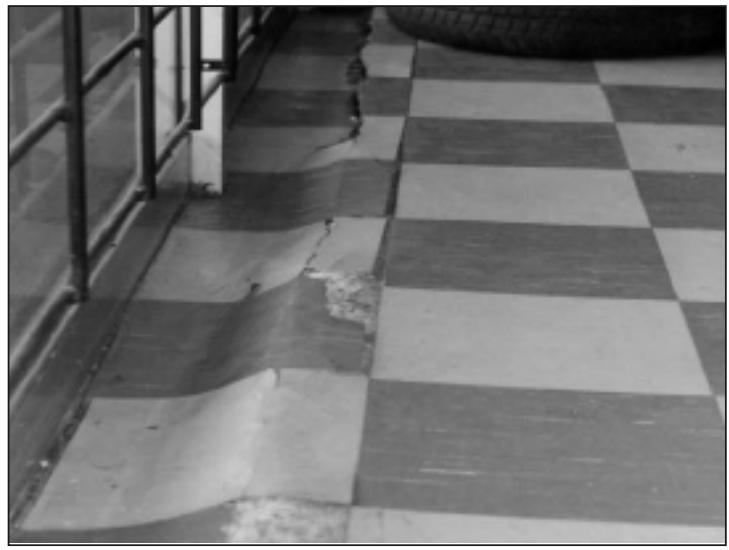

Figure 8

(Bryant 2003)

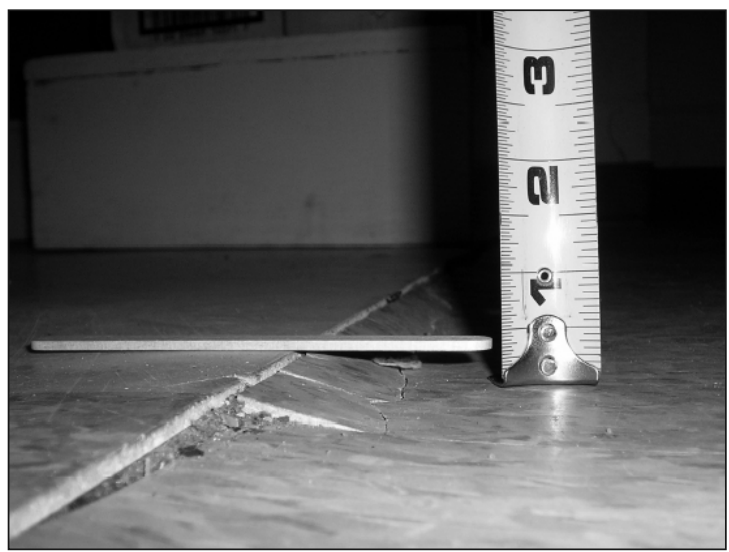

Figure 9

The Effect of Pyrite Expansion 
Copyright @ National Academy of Forensic Engineers (NAFE) http://www.nafe.org. Redistribution or resale is illegal. Originally published in the Journal of the NAFE volume indicated on the cover page. ISSN: 2379-3252

\section{Effect}

In addition to the conditions above, the lifting of the slab has in 2005 resulted in the structural impact to the building. The interior wall adjacent to the end classroom is a shear wall. This is a wall that transfers the horizontal wind load on the building from the walls to the foundation. The location of shear walls is shown in the Figure 10.

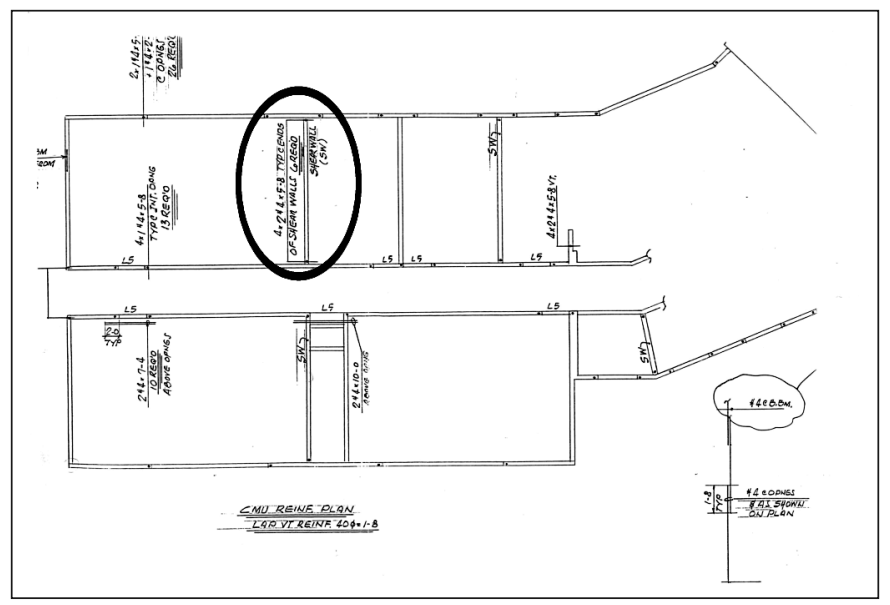

Figure 10

Floor Plan

One such location, where the wind forces are transferred into the shear wall is at the location depicted in the circle. Without this connection the forces imposed by the wind would have to be resisted by the exterior wall alone, and from our earlier work at the school we know these walls alone are incapable of resisting these forces.

\section{Impact}

The impact of the expansion of the underlying soil continues to lift not only the slab, but also the shear wall resting on the slab. The wall is connected to the structural bar joist through a series of plate connections. This is how the exterior wall and the roof diaphragm forces are delivered from the wind into the joist and then into foundation.

As the interior wall has lifted, the travel available in the slotted connections has diminished. The connecting bolt was discovered to be in the top of the slotted connection in August 2005.

The wall, which rests on the upward moving floor slab, was now lifting the structural joist. In August 2005 it was discovered that the joists adjacent to the two shear walls had been loaded upward to a point where it had broken free of the 
exterior wall. It was also noted that the joist located approximately four-feet on either side of the shear wall were also disconnected from the exterior wall. The joist's functioning as a load-transmitting member to resist the forces of wind load on the building was in serious question. Remediation was essential, and the attachment shown in Figure 11 was effected.

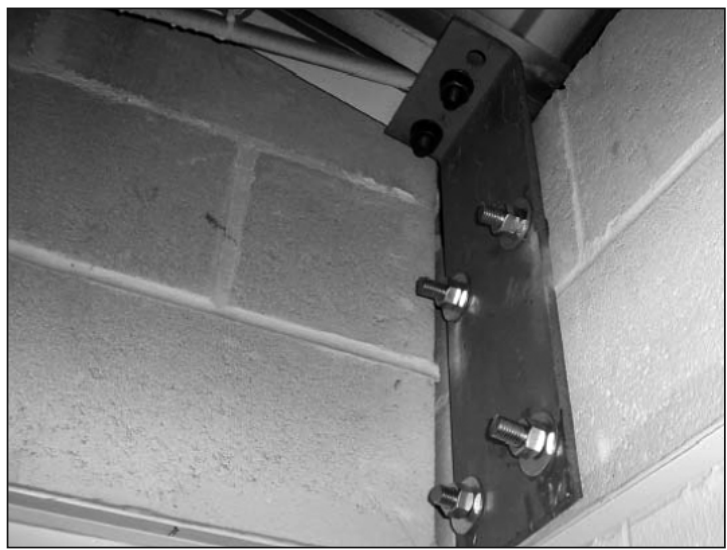

Figure 11

Remediation Measure

Our attention immediately focused on what magnitude of force would be required to raise the roof sufficiently to cause the pullout of three bearing plate anchors. Each plate had a $1 / 2$ - inch diameter stud anchor with 6-inches of embedment. The force required to uplift the bearing plate was calculated at approximately 3000-pounds. Considering the weight of the shear wall and the supporting slab, the uplift force would only need $\sim 6$ psi, or approximately $59 \%$ of the reported potential 10 psi force caused by pyrite expansion.

The impact of the fill material's expansion has had, and continues to have a significant deleterious impact on the building.

\section{Quantification and Results}

The situation at the elementary school posed a significant challenge to the district. The reality is that if there were no water / air fluctuations within the soil matrix to initiate the oxidation process, the expansion of the fill material may have been avoided. That is however speculative at this time since there was no footing drain designed, and none installed in the original construction.

The material that had been installed under the slab was 'crusher dust' produced at the local quarry. It is believed that the material was produced and delivered in1998. Upon the initiation of our investigation, we had collected various samples. We have the core samples retrieved in 2003. We have the quarry samples collected in 2003. In 2005 we added the samples from the core penetrations when the footing drain was installed. Each of these represents either a condition when the material had undergone certain reactions already [2003 core and 2005 core samples], or was produced at a time other than that during which the stone dust was installed [1998 core samples and 2003 quarry sample]. We 
Copyright () National Academy of Forensic Engineers (NAFE) http://www.nafe.org. Redistribution or resale is illegal. Originally published in the Journal of the NAFE volume indicated on the cover page. ISSN: 2379-3252

needed a sample from 1998, which had not undergone the phase change to the degree of the core samples.

The same material installed at the elementary school was also installed in the basement area of the middle school, under the gymnasium. In the adjacent crawl space it was found that the material was relatively dry, and remained gray in color, unchanged by the oxidation process. A sample was collected from this location for analysis. This sample would represent the closest we could find to that which was installed in 1998 and which had not undergone the phase change noted in the elementary school core samples.

The samples were analyzed to determine the presence of sulfur in the material. The presence of pyrite would be a source of this sulfur. The test conducted was the hydrogen peroxide oxidation test as described below.

\section{Hydrogen peroxide oxidation test}

Hydrogen peroxide $\left(\mathrm{H}_{2} \mathrm{O}_{2}\right)$ oxidation testing is commonly used in soil science and mining discipline to determine the acid-producing potential of a geo-material. This test method is based upon the use of hydrogen peroxide $\left(30 \% \mathrm{H}_{2} \mathrm{O}_{2}\right.$ in deionized water) to rapidly oxidize pyrite, producing sulfuric acid $\left(\mathrm{H}_{2} \mathrm{SO}_{4}\right)$ and iron hydroxide $\left(\mathrm{Fe}(\mathrm{OH})_{3}\right)$. The net amount of sulfuric acid produced by oxidation with hydrogen peroxide is then determined by titration with sodium hydroxide.

\begin{tabular}{|c|c|c|c|c|}
\hline \multicolumn{5}{|c|}{ Sample Analysis } \\
\hline & & $\mathrm{NaOH}(0.01 \mathrm{M})$ & Meq. $\mathrm{H}+$ & $\% S$ \\
\hline $1 \mathbf{a}$ & 2003 Quarry Sample & 32.4 & 16.20 & 0.22 \\
\hline 1b & Stone dust colected & 33.4 & 16.70 & 0.23 \\
\hline $1 c$ & from stock pile & 34.3 & 17.15 & 0.24 \\
\hline $3 \mathbf{a}$ & Under floor slab & 11.0 & 5.50 & 0.02 \\
\hline $3 \mathbf{b}$ & installed 1998 & 13.0 & 6.50 & 0.04 \\
\hline $3 c$ & sample July 2003 & 12.7 & 6.35 & 0.04 \\
\hline $4 a$ & North Footing & 13.8 & 6.90 & 0.05 \\
\hline $4 b$ & installed 1998 & 13.2 & 6.60 & 0.04 \\
\hline $4 c$ & sample July 2005 & 13.5 & 6.75 & 0.04 \\
\hline $5 a$ & South Footing & 16.4 & 8.20 & 0.07 \\
\hline $5 b$ & installed 1998 & 16.4 & 8.20 & 0.07 \\
\hline $5 c$ & sample July 2005 & 15.7 & 7.85 & 0.06 \\
\hline $6 a$ & Middle School & 44.1 & 22.05 & 0.33 \\
\hline $6 b$ & Crawl Space & 43.8 & 21.90 & 0.32 \\
\hline $6 c$ & $\begin{array}{l}\text { installed } 1998 \\
\text { collected August } 2005\end{array}$ & 43.3 & 21.65 & 0.32 \\
\hline$* 2$ & Sample 2 destroyed & & & \\
\hline
\end{tabular}

Table 1

Test Results 
Copyright @ National Academy of Forensic Engineers (NAFE) http://www.nafe.org. Redistribution or resale is illegal. Originally published in the Journal of the NAFE volume indicated on the cover page. ISSN: 2379-3252

Recalling from the previous sections that minute quantities (less than $0.1 \%$ ) of sulfur could cause the swell reaction and expansive forces to begin, we tested the material for sulfur content (Belgeri and Siegel, 1998). The test results for the samples are presented in Table 1.

Accepting that the material collected in the middle school crawl space is representative of the elementary school fill material the test results show that with $0.32 \%$ sulfur there was an adequate amount of sulfur present to initiate the reaction for heave. The Figure 12 shows the potential for heave given various levels of sulfur. Of course this is a generic graph, which only provides a limited understanding of the potential for heave at the elementary school, however it is somewhat informative, and agrees with our movement thus far. The overall potential for swell suggests that upwards of 5 inches of movement might be expected.

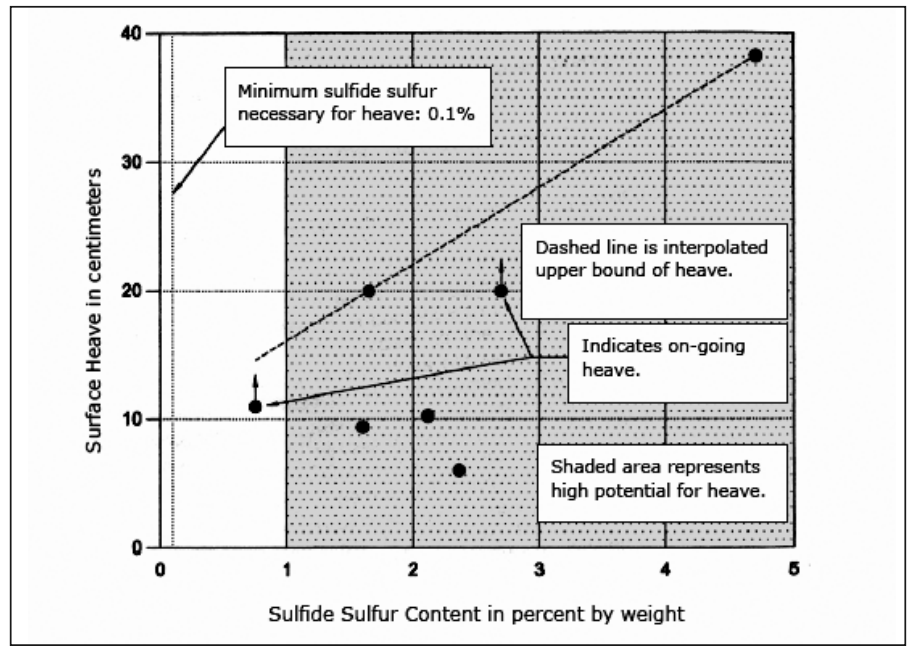

Figure 12

Potential For Expansion (Bryant 2003)

\section{District-wide Problem}

Once it was confirmed that there was indeed sulfur material present, and that the distress at the elementary school was the likely result of these expansive forces, the other schools where the material had been placed were investigated thoroughly. Up until this time it had been thought that the slab problem was isolated to the elementary school. Upon inspection it was found that the same conditions existed in the middle school and high school.

The extensive nature of the problem now encompasses the new gymnasium $(\sim 15,000$ square feet $)$ at the middle school and the new auditorium and adjacent areas $(\sim 18,000$ square feet) at the high school. 
Copyright @ National Academy of Forensic Engineers (NAFE) http://www.nafe.org. Redistribution or resale is illegal. Originally published in the Journal of the NAFE volume indicated on the cover page. ISSN: 2379-3252

While the chemical process has not yet reached the intensity of that of the elementary school, all indications are that with time, it will. The pyrite oxidation process has begun.

\section{Conclusions}

Once the oxidation process has begun, the ability to halt its action is essentially non-existent. The rate of movement, and building failure may be expected to increase with time. This is supported by the tracking of building rate of movement over time as presented in Figure 13

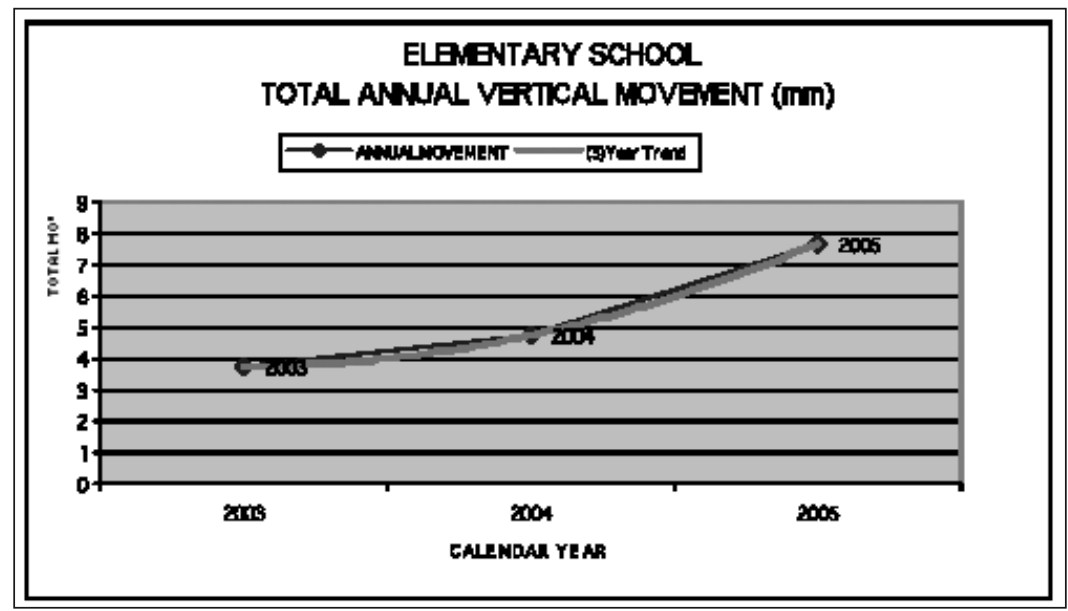

Figure 13

The solution to the problem at the elementary school will likely be dramatic. While the recently installed footing drains will remove water from the space adjacent to the foundation wall, and will allow the soils within the foundation to dry out, the long-term implications of the pyrite expansion are not good.

Bryant outlines the time-rate implications of pyrite oxidation:

"While time-rate relationships help with engineering design and expected structure life, the weathering of sulfidic material is a continuing process that builds upon itself. The rate of expansion will likely increase as the rock becomes more fractured, allowing more aerated water to interact with the un-weathered pyritic material" (Bryant 2003).

The implication here is that as the expansion takes place, the previously compacted material expands, thus becoming less dense and allowing more water to penetrate into the material, advancing the process. 
Copyright @ National Academy of Forensic Engineers (NAFE) http://www.nafe.org. Redistribution or resale is illegal. Originally published in the Journal of the NAFE volume indicated on the cover page. ISSN: 2379-3252

Further, we know from the chemical test results that even at the elementary school, where much of the oxidation has already taken place, there remains unoxidized pyritic material present.

The solution to the situation in a Library in Tennessee is described in the summary of Figure 14.

\subsection{Sulfide-induced heave study, Johnson City Public Library, Johnson City, Tennessee}

The Johnson City Public Library, located in Johnson City, Tennessee, was constructed in 1979 (Belgeri and Siegel 1998). The library structure experienced significant levels of cracking of floor slabs and buckling of floors and partition walls by 1982 (Figure 2.1). Damage was particularly significant in areas constructed over fill. The floor slab was vertically displaced $2-3 \mathrm{~cm}$ at construction joints and differential vertical displacements were as much as $11 \mathrm{~cm}$ within a given room (Belgeri and Siegel 1998). Damage resulting from shale heave occurred much more quickly in areas constructed over the shale fill as opposed to over the undisturbed shale. Heave in the fill sections occurred within three years, while the undisturbed shale sections took eight years for heave damage to occur. This time difference is due to several factors. The shale fill has a greater exposed surface area than the undisturbed material. Thus, more material is available for pyrite oxidation and gypsum formation reactions. The greater permeability of the fill would also give it greater access to air and water, which would accelerate the rates of reactions producing swelling materials. The extent of damage to the library was so significant that the building was finally demolished in 2000 . The very short life of this

\section{Figure 14 \\ (Bryant 2003)}

The situation at the case study elementary school is not much different, or the prognosis much better than that of the Tennessee Library. The photo of the movement gage installed on February 23, 2005 is shown in Figure 15. This picture shows that the movement in eight month's time has now been in the vertical and the horizontal direction.

The continued movement of the building can only be attributed to the force of the pyritic expansion. We know that the building is continuing to move, and we know from the breaking of the tail of the roof joist from the exterior wall in the summer of 2005 that this movement creates a condition where the structural integrity of the building is in question.

Evidence of the expansive forces now moving the foundation of the structure in the horizontal direction is shown in the movement gage and in the exte- 


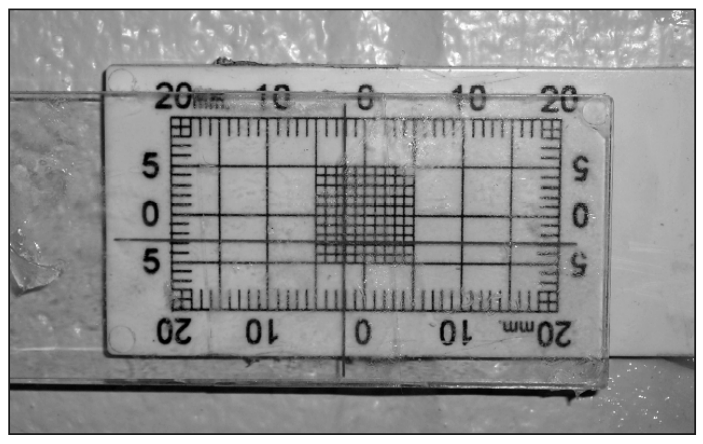

Figure 15

Movement Gage installed July 2005 Observed November 10, 2005

rior wall being pushed outward from the interior shear wall. The movement is greater in the lower portion of the wall than the upper wall area, where the roof joist restrains it. This creates an untenable situation.

As a result of this, and the evidence of the potential for a dramatic structural failure, the elementary school building was closed in January 2006, following our recommendation. The middle school and high school continue to undergo monitoring to ensure the structural safety of those facilities.

It has become clear that over time that these facilities will require extensive remedial work. The pyritic material will be removed and replaced with a non-expansive material, and the structure reconstructed to its original intended condition.

\section{Legal Disposition}

The subject case of this paper was resolved in an out of court settlement concluded in 2009. The case had been scheduled for trial for the fall of 2008, yet the Judge assigned to the case conducted a mediation session in August of 2008. It was this mediation session that initiated meaningful discussion toward settlement.

Since the time of the initial paper it had been discovered that similar problems were present and the rate of failure within the High School and Middle School were accelerating. As a result, the District initiated immediate plans for a phased repair of these two facilities. The Middle School was remediated in the summer of 2007. The High School was remediated in the summer of 2008. Essentially every addition constructed as part of the 1997 Capital Project was found to have pyrite laden granite stone dust as fill, and therefore was subject to failure.

Following extensive fact witness depositions and discovery it was, in practical terms an accepted fact that the author's analysis of the mode of failure pyrite induced expansion - was the cause of the movement and distress. The case then came down to a contract case, and the evaluation of whether there was a breach in the duties of the parties in the proposal, review, acceptance and installation of the granite stone dust used in this application. 
Copyright @ National Academy of Forensic Engineers (NAFE) http://www.nafe.org. Redistribution or resale is illegal. Originally published in the Journal of the NAFE volume indicated on the cover page. ISSN: 2379-3252

The parties remaining in the case at that time were: 1] the Architect, 2] the Structural Engineering sub-consultant to the architect, and 3] the Construction Manager.

In New York State, expert witnesses are not routinely subjected to pre-trial depositions. As such, the case that was to be presented at trial and the testimony of the experts for the District were not available to the defense for inquiry. However, it was agreed by all parties that the Court would undertake an effort to mediate the case, with all parties present, and that the mediation would begin with a complete presentation by the District expert [the paper's author] of our theories as to how the use of the pyritic stone dust occurred, and its impacts on the District's structures.

Following the presentation questions were posed of the experts by opposing counsel and answers were provided. Once the questions were exhausted, the parties went to separate rooms while the Judge worked among those parties with positions, offers and counter-offers. The mediation broke for the day and continued for several weeks thereafter until a settlement was reached among the parties. The following news account made the case public and summarizes the settlement of the matter:

"The judge was on vacation at his camp, one lawyer was at Disney World with his family, the other was pulled over on the side of the Northway, and the superintendent was eating dinner when the 6 o'clock deadline for a settlement offer hit on Wednesday. Several hurried cell phone calls later, the School District settled a lawsuit that has dragged on for five years - and a problem that began 10 years ago.

"The lawsuit stems from the 1997-98 faulty capital project construction that required most of the work to be redone over the last four years.

"When the construction of the high school is completed, we can say that the capital project of 1997 is done," School board President Debra Lennon said. "Now we can look forward and ahead to the future without this thing hanging over our heads."

"Dirt was the culprit of this lawsuit. Defective fill that was used during the construction at the elementary, the middle schools and the high school contained pyrite, or fool's gold, which expands and contracts with changes in moisture and temperature. This movement caused the heavy concrete slabs that rested on it to move, subsequently cracking and causing walls and door frames to move as well. 
Copyright @ National Academy of Forensic Engineers (NAFE) http://www.nafe.org. Redistribution or resale is illegal. Originally published in the Journal of the NAFE volume indicated on the cover page. ISSN: 2379-3252

"The money will be paid by architects, structural engineer and the construction manager, with the architect paying the largest amount.

According to the school's lawyer on this case the school had a contract with the architect that said the firm had ultimate responsibility and was the ultimate decision-maker on any substitutions, including the substitution of the fill."

In closing: It is the opinion of the author that this case was able to be settled among the parties due in large part to the detailed Forensic Engineering assessment and investigation. Once the Forensic Engineering of the case was completed, all parties understood the reason for the building movement and distress. The Forensic Investigation essentially allowed settlement discussions to focus on legal, rather than technical matters.

\section{Acknowledgements}

The author sincerely acknowledges the contributions to this paper from Mr. Joseph L. Thesier, P.E. ${ }^{2}$ and Mr. Mark B. Kimball, P.E. principals in the firm Bernier-Carr and Associates, P.C. of Watertown, New York. Without their professional investigation and technical contributions these discoveries would not have been possible.

\section{References}

1. Belgeri, J. J., and Siegel, T. C., Design and Performance of Foundations on Expansive Shale, Ohio River Valley Soils Seminar, XXIX, Louisville, KY. 1998

2. Bryant, Lee Davis, Master of Science in Civil Engineering Dissertation, "Geotechnical Problems with Pyritic Rock and Soil", Virginia Polytechnic Institute and State University, May 2003

3. Kulhawy, Fred, P.E., G.E., Hon. M.ASCE Professor, Cornell University, Personal Communication, 2005

4. O'Rourke, Thomas D., NAE, Professor, Thomas R. Briggs Professor of Engineering, Cornell University, Personal Conversation 2005

5. Mitchell, James K., Soga, Kenichi, Fundamentals of Soil Behavior, Third Edition, John Wiley and Sons, Hoboken, New Jersey, 2004 